\title{
Evaluation of Air Pollution Tolerance Index and Anticipated Performance Index of Selected Plant Species
}

\author{
Winifred Uduak Anake ${ }^{1, *}$, Jacinta Eigbefoh Eimanehi ${ }^{1}$, and Conrad Asotie Omonhinmin ${ }^{2}$ \\ ${ }^{1}$ Department of Chemistry, College of Science and Technology, Covenant University, \\ Km 10, Idiroko Road, Ota, Ogun State, Nigeria \\ ${ }^{2}$ Department of Biological Sciences, College of Science and Technology, Covenant University, \\ Km 10, Idiroko Road, Ota, Ogun State, Nigeria
}

${ }^{*}$ Corresponding author:

email:

winifred.anake@covenantuniversity.edu.ng

Received: May 4, 2018

Accepted: June 28, 2018

DOI: $10.22146 /$ ijc. 35270

\begin{abstract}
This study reports a combination of two indices, air pollution tolerance index (APTI) and anticipated performance index (API) as viable tools for selecting suitable plants for pollution abatement program. Leaf samples of 6 plant species; Mangifera indica, Araucaria heterophylla, Elaeis guineensis, Syzygium malaccense, Acacia auriculiformis, and Chrysophyllum albidium were collected from an industrial and academic areas at Ado-Odo, Ota, Nigeria; during the dry season of January to March 2018. Biochemical parameters; leaf-pH, relative leaf water content, total chlorophyll content, and ascorbic acid content were analyzed to compute the APTI values. Combined APTI, botanical and socioeconomic indices were graded to evaluate the API of the different plant species. The APTI for the species ranged between 4.79 and 10.7, ideal for sensitive species category (APTI < 11), and the plants are classified as bio indicators of air pollution. The API indicates Mangifera indica and Syzygium malaccense $(A P I=4)$ as good performers while Chrysophyllum albidum is a moderate performer $(A P I=3)$. The three tree species were identified as suitable green belt plants and thus valuable additions to the green belt development plant list in tropical Africa.
\end{abstract}

Keywords: air pollution control; plants; bio-indicators; air pollution tolerance index; anticipated performance index

\section{INTRODUCTION}

Air pollution is the introduction of chemicals, biological materials or particulate matter which includes sulfur oxide, nitrogen oxide, carbon monoxide, soot particles, toxic metals, organic molecules and radioactive isotopes into the atmosphere in a concentration capable of causing damage to living organisms, humans and the environment [1-2]. Vegetation, shrubs, plants, and trees have been confirmed by several researchers as a green way of combating ambient air pollution challenge [3-6]. These have resulted in the wide screening, identification and recommendation of green plants in the form of green belts and urban green spaces for air pollution mitigation $[3,6-$ $8]$.
The leaf parameters such as total chlorophyll content (TCC), ascorbic acid content (AAC), relative water content (RWC), and leaf extract $\mathrm{pH}$ are combined to estimate the air pollution tolerance index (APTI) [46]. The combination of APTI value along with some biological and socio-economic characters of plant generates a unique index known as the anticipated performance index (API). APTI and API have been employed by several researchers to identify plant species that are tolerant or receptive to pollution in the urban environments [6-8].

A major source of air pollution in Ado-Odo, Ota, and its environment stems from the uncontrolled gaseous and particulate emission from industrial 
activities and transportation [9-10]. In Nigeria, only one research has been published on the selection of four plants species (T. catappa, V. paradoxa, A. nilotica and P. africana) suitable for the control of pollution via a combination of APTI and API [7]. Based on the aforementioned air pollution challenges, there is a need to carry out intensive screening of several plant species for sensitive and tolerance potentials suitable for ambient air pollution control with respect to their local environment.

\section{- EXPERIMENTAL SECTION}

\section{Materials}

Leaves of six matured tree species namely Mangifera indica, Elaeis guineensis, Araucaria heterophylla, Syzygium malaccense, Acacia auriculiformis and Chrysophyllum albidium predominantly common in the study locations were collected in triplicates. The study locations used were Industrial Site Ota (ISO) and Academic Site Canaan Land (ASC) both in Ado-Odo, Ota, in Ogun State, Nigeria.

\section{Instrumentation}

The instrument used were an Ultraviolet spectrophotometer, HANNA Microprocessor pH 211 meter, Weighing balance, Centrifuge, Oven, Refrigerator and Hand-held global positioning system (GPS).

\section{Procedure}

\section{Study area and sample collection}

In this study, five sample sites were considered and designated as HNO $(6.6813 \mathrm{~N} 3.1956 \mathrm{E})$, GPO $(6.6744 \mathrm{~N}$ 3.1997E), CTC $(6.6731 \mathrm{~N} 3.1586 \mathrm{E})$, CDC $(6.6743 \mathrm{~N}$ $3.1586 \mathrm{E})$ and PQC (6.6833N 3.1626E). Samples were collected early hours of the morning between 7.00 a.m. and 11.00 a.m. the same day from January to March 2018. Collected leaf samples were wrapped in foil paper, preserved in ice chest box and transported immediately to the laboratory for identification, preparation, and preservation.

\section{Determination of biochemical parameters}

The biochemical parameters analyzed were relative water content, $\mathrm{pH}$ of leaf extract, total chlorophyll content and ascorbic acid content. The $\mathrm{pH}$ of leaf extract was determined using a glass electrode $\mathrm{pH}$ meter according to [3]. The relative water content was determined using a modified method of [11] as shown:

$\mathrm{RWC}=\frac{\mathrm{Fw}-\mathrm{Dw}}{(\mathrm{Tw}-\mathrm{Dw})} \times 100$

where, Fw is the fresh weight, Dw is the dry weight and $\mathrm{Tw}$ is the turgid weight. The leaves were immersed in water for $24 \mathrm{~h}$ and blotted to dryness to obtain the turgid weight while the dry weight of turgid leaves was obtained after oven drying at a temperature of $60^{\circ} \mathrm{C}$. The ascorbic acid content of leaves was determined using the spectrophotometric method. $4 \mathrm{~mL}$ of oxalic acid-EDTA, $1 \mathrm{~mL}$ of orthophosphoric acid, $2 \mathrm{~mL}$ of $5 \%$ tetraoxosulfate(VI) acid, $4 \mathrm{~mL}$ of ammonium molybdate and $3 \mathrm{~mL}$ of water were used as extractant for $1 \mathrm{~g}$ of the fresh leaves in a beaker. The solution was allowed to stand for $15 \mathrm{~min}$ and filtered into test tubes after which the absorbance at $760 \mathrm{~nm}$ was measured with an ultraviolet spectrophotometer. The concentration of ascorbic acid in the sample was then extrapolated from a standard ascorbic acid curve [12]. The total chlorophyll content was determined according to Arnon equation [13-14]. This was done by centrifuging $15 \mathrm{~mL}$ of leaf extract and $80 \%$ acetone for $3 \mathrm{~min}$ at 2,500 rpm for thorough separation. The liquid portion was decanted and their absorbance was taken at 645 and 663 $\mathrm{nm}$ using an ultraviolet spectrophotometer. Further calculations were performed to determine the chlorophyll content of leaf extract according to Arnon equation [13-14].

\section{Determination of air pollution tolerance index (APTI)}

The APTI was proposed by Singh [15] following the formula:

$\mathrm{APTI}=\mathrm{A}(\mathrm{T}+\mathrm{P})+\mathrm{R} / 10$

where $\mathrm{A}$ is the ascorbic acid content (mg/g), $\mathrm{T}$ is the total chlorophyll content $(\mathrm{mg} / \mathrm{g}), \mathrm{P}$ is the $\mathrm{pH}$ of the leaf extract, and $\mathrm{R}$ is the relative water content of leaf (\%). Using values of APTI, plants were classified based on their tolerance level to air pollution as follows: $\geq 17$ as tolerant, $12-16$ as intermediate tolerant and $1-11$ as sensitive [4-6]. 


\section{Determination of anticipated performance index (API)}

The APTI value, along with various plant parameters including plant habit, canopy structure, type of plant, size, texture, hardiness and the economic value was employed in API computation following the grade distribution pattern according to [7,11]. Anticipated performance index (API) can be calculated as follows:

API $=\frac{\text { No. of " }+ \text { " obtained }}{\text { Total No. of "+" }}$ x100

After which, various categories of plant species are assigned based on their API scores (\%) as follows: $<30$ as not recommended, $31-40$ as very poor, $41-50$ as poor, $51-$ 60 as moderate, $61-70$ as good, $71-80$ as very good, $81-90$ as excellent and $91-100$ as best [7-11].

\section{- RESULTS AND DISCUSSION}

\section{Leaves Biochemical Parameters of Air Pollution Affected Tree Species}

$\mathrm{pH}$ regulation in the cellular compartment of the plant is important for intracellular transportation of vesicles, protein, small molecules and hormones [18]. As shown in Table 1, the $\mathrm{pH}$ value of all samples in both sites ranges from 3.55 to 7.32 . Pollutant exposed plants, most especially $\mathrm{SO}_{2}$, produces massive $\mathrm{H}^{+}$to react with $\mathrm{SO}_{2}$. Resulting in the generation of $\mathrm{H}_{2} \mathrm{SO}_{4}$, as such the leaf $\mathrm{pH}$ reduces. Plants with low leaf $\mathrm{pH}$ indicate a reduction in the photosynthetic process and show a positive correlation with sensitivity to air pollution $[7,19]$. In addition, higher $\mathrm{pH}$ in a plant increases the rate at which hexose sugar is converted to ascorbic acid as well as the tolerance capacity of the plants $[4,20]$.

RWC of a leaf reflects the amount of water present in response to its full turgidity. The higher relative water content of $98.1 \%$ was observed in Araucaria heterophylla cultivated in the industrial site (ISO), and the least $45.8 \%$ was recorded by Syzygium malaccense in the academic site. Exposure to air pollution increases the density of plant stomata, resulting in a decrease in the water content of the plant's tissues. Hence, the higher the water content of a plant, the greater the plant's ability to maintain its physiological balance and to tolerate pollution and pollution stress conditions $[7,18]$.

As shown in Table 1, the highest total chlorophyll content $(\mathrm{mg} / \mathrm{g}$ ) was observed in Elaeis guineensis (0.614) in the academic site, and the least was observed for Mangifera indica (0.337) in the industrial site. The TCC content in plant leaves decreases with increase deposition of particulate matter and gaseous pollutants on the leaf surface, as well as due to drought, salt stress, and heavy metals accumulation in the soil $[3,18,20]$. As such, low TCC indicates the sensitivity of plant to pollution while high TCC in plant leaves indicates their tolerance potential in the polluted environment [21].

Biochemical analysis of plants across the study sites revealed that Chrysophyllum albidum (2.23) and Syzygium malaccense (0.541) in ASC, recorded the highest and least ascorbic acid contents respectively. Ascorbic acid content in plants helps to prevent the damaging effect of air pollution on plant tissues. High AAC in plants increases tolerance to pollution as a result of its high antioxidant potential. Conversely, plants with low AAC, exhibits low antioxidant potential, low tolerance and hence high sensitivity to air pollution [8,22-23].

\section{Air Pollution Tolerance Index (APTI)}

An environment air quality status can be improved via the identification and cultivation of plants capable of

Table 1. Biochemical parameters and air pollution tolerance indices (APTI) of the studied plant species in ISO and ASC

\begin{tabular}{lcllcccccc}
\hline Study area & Sample site & \multicolumn{1}{c}{ Taxon } & Common name & $\mathrm{P}$ & $\mathrm{R}(\%)$ & $\mathrm{T}(\mathrm{mg} / \mathrm{g})$ & $\mathrm{A}(\mathrm{mg} / \mathrm{g})$ & APTI & Rating \\
\hline ISO & HNO & Araucaria heterophylla & Norfolk pine & 6.71 & 98.1 & 0.435 & 0.583 & 10.2 & Sensitive \\
& GPO & Mangifera indica & Mango & 6.14 & 68.8 & 0.337 & 1.77 & 8.03 & Sensitive \\
& & Elaesis guineensis & Oil palm & 7.32 & 70.6 & 0.614 & 1.06 & 7.90 & Sensitive \\
\hline ASC & PQC & Acacia auriculiforms & Ear pod & 7.01 & 92.8 & 0.466 & 1.87 & 10.7 & Sensitive \\
& CDC & Chrysophyllum albidum & African star apple & 6.10 & 89.6 & 0.514 & 2.23 & 10.4 & Sensitive \\
& CTC & Syzygium malaccense & Malay apple & 3.55 & 45.8 & 0.452 & 0.541 & 4.79 & Sensitive \\
\hline
\end{tabular}


Table 2. Evaluation of plant species based on their APTI values, biological parameters and socioeconomic importance

\begin{tabular}{|c|c|c|c|c|c|c|c|c|c|c|}
\hline \multirow{2}{*}{ Taxon } & \multirow{2}{*}{ APTI } & \multirow{2}{*}{$\mathrm{PH}$} & \multirow{2}{*}{ CS } & \multirow{2}{*}{ TT } & \multirow{2}{*}{ LT } & \multirow{2}{*}{ LS } & \multirow{2}{*}{ EI } & \multirow{2}{*}{ Hardiness } & \multicolumn{2}{|c|}{ Grade allotted } \\
\hline & & & & & & & & & Total plus (+) & Scoring \% \\
\hline Mangifera indica & - & ++ & ++ & + & + & ++ & ++ & + & 11 & 68.8 \\
\hline Araucaria heterophylla & + & ++ & + & + & + & - & + & + & 8 & 50 \\
\hline Elaesis guineensis & - & ++ & + & + & + & - & ++ & + & 8 & 50 \\
\hline Acacia auriculiforms & + & + & + & + & - & - & ++ & + & 7 & 43.8 \\
\hline Syzygium malaccense & - & ++ & ++ & + & + & ++ & ++ & + & 11 & 68.8 \\
\hline Chrysophyllum albidum & + & ++ & + & + & + & - & ++ & + & 9 & 56.2 \\
\hline
\end{tabular}

APTI: Air pollution tolerance index; PH: Plant habit; CS: Canopy structure; TT: Type of tree; LS: Laminar size; LT: Laminar texture; EI: Economic importance and $\mathrm{H}$ : Hardiness

Table 3. Anticipated performance index (API) value of the studied plant species

\begin{tabular}{clcccc}
\hline \multirow{2}{*}{ Sample code } & \multirow{2}{*}{ Taxon } & \multicolumn{2}{c}{ Grade allotted } & \multirow{2}{*}{ API value } & Assessment \\
\cline { 3 - 5 } & & Total plus (+) & Percentage (\%) & & \\
\hline \multirow{2}{*}{ ISO } & Mangifera indica & 8 & 68.8 & 4 & Good \\
& Elaesis guineensis & 8 & 50 & 2 & Poor \\
& Araucaria heterophylla & 7 & 43.8 & 2 & Poor \\
\hline \multirow{2}{*}{ ASC } & Acacia auriculiforms & 9 & 56.2 & 3 & Poor \\
& Chrysophyllum albidum & 11 & 68.8 & 4 & Goderate \\
& Syzygium malaccense & & & & Good \\
\hline
\end{tabular}

gases and particles removal from surrounding air. APTI provides information on plants based on sensitivity and tolerance to air pollutants using the biochemical parameters and APTI grading system. Results of APTI for each plant species studied is shown in Table 1. The APTI values of the plant species for ISO and ASC ranged from 7.90 to 10.2 and 4.79 to 10.7 , respectively. Plant species in ISO and ASC can be considered sensitive species since the values recorded fell within the APTI range of 1 to 11 $[4,6,24]$. Hence, the investigated plant species can be assigned air pollution bio-indicators status. Syzygium malaccense with 4.79 APTI value was the most sensitive amongst the species studied and was obtained from ASC.

\section{Anticipated Performance Index (API)}

The API score categories were used in allotting scores for different selected plants as shown in Table 2 and 3. Plant species found under API category of excellent, very good, good and moderate performers can be recommended for cultivation as green belts species [3,11,25-26]. The API results in Table 3 indicate Mangifera indica and Syzygium malaccense as good performers while Chrysophyllum albidum was seen as a moderate performer. Though the three tree species are all sensitive plants and of moderate height following the results of their biochemical parameters and tree size respectively, Mangifera indica and Syzygium malaccense are distinguished as good performers because of their broader leaf size, compact crown and greater economic importance [11,17,22]. Based on API grading the plants are classified as reliable green belt performers and suggested as ideal species for green belts development in the study area. However, Araucaria heterophylla, Elaeis guineensis and Acacia auriculiforms were categorized as poor and cannot be recommended for green belt programs. This categorization is linked to the poor surface areas of the linear to needle leaf shape and size of these plant species.

\section{- CONCLUSION}

Six plants have been identified and classified based on APTI sensitivity scheme for plant towards air pollutants. Syzygium malaccense tree in ASC is the most suitable bio-indicator for air pollution. Three of the six plant species satisfied the API grading for green belt species ranging from good to moderate performers. 
These trees; Mangifera indica, Syzygium malaccense, and Chrysophyllum albidum can be integrated into a green belt design for air pollution control project for the Ota Industrial Site.

\section{- ACKNOWLEDGMENTS}

The authors appreciate Covenant University for the provision of resources, and a research base for this work. Also, Mr. Ogunleye O. Moses, Mrs. Jonathan Hassan, Miss. Owolabi F. Elizabeth and Mr. Jolayemi E. Gbenga for laboratory and instrumental analysis assistance.

\section{- REFERENCES}

[1] Dhankhar, R., Mor, V., Lilly, S., Chopra, K., and Khokhar, A., 2015, Evaluation of anticipated performance index of some tree species of Rohtak City, Haryana, India, IJRSR, 6 (3), 2890-2896.

[2] Bhattacharya, T., Kriplani, L., and Chakraborty, S., 2013, Seasonal variation in air tolerance index of various plant species of Baroda City, UJERT, 3 (2), 199-208.

[3] Pandey, A.K., Pandey, M., Mishra, A., Tiwary, S.M., and Tripathi, B.D., 2015, Air pollution tolerance index and anticipated performance index of some plant species for development of urban forest, Urban For. Urban Greening, 14 (4), 866-871.

[4] Bharti, S.K., Trivedi, A., and Kumar, N., 2017, Air pollution tolerance index of plants growing near an industrial site, Urban Clim., 24, 820-829.

[5] Mondal, D., Gupta, S., and Datta, J.K., 2011, Anticipated performance index of some tree species considered for green belt development in an urban area, IRJPS, 2 (4), 99-106.

[6] Sahu, C., and Sahu, S.K., 2015, Air pollution tolerance index (APTI), anticipated performance index (API), carbon sequestration and dust collection potential of Indian trees species - A review, IJERMT, 4 (11), 37-40.

[7] Patel, D., and Nirmal Kumar, J.I., 2018, An evaluation of air pollution tolerance index and anticipated performance index of some tree species considered for green belt development: A case study of Nandesari industrial area, Vadodara, Gujarat, India, OJAP, 7 (1), 1-13.

[8] Ogunkunle, C.O., Suleiman, L.B., Oyedeji, S., Awotoye O., and Fatoba, P.O., 2015, Assessing the air pollution tolerance index and anticipated performance index of some tree species for biomonitioring environmental health, Agrofor. Syst., 89 (3), 447-454.

[9] Anake, W.U., Benson, N.U., and Ana, G.R.E.E., 2016, Characterization of airborne fine particulate matter $\left(\mathrm{PM}_{2.5}\right)$ and its air quality implications in Ogun State, Nigeria, The $3^{\text {rd }}$ International Conference on African Development Issues (CUICADI 2016), 9-11 May 2016, Covenant University, Ota, Nigeria, 543-547.

[10] Anake, W.U., Ana, G.R.E.E., Williams, A.B., FredAhmadu, O.H., and Benson, N.U., 2017, Chemical speciation and health risk assessment of fine particulate bound trace metals emitted from Ota Industrial Estate, Nigeria, IOP Conf. Ser. Earth Environ. Sci., 68, 012005.

[11] Pathak, V., Tripathi, B.D., and Mishra, V.K., 2011, Evaluation of anticipated performance index of some tree species for green belt development to mitigate traffic generated noise, Urban For. Urban Greening, 10 (1), 61-66.

[12] Prajapati, S.K., and Tripathi, B.D., 2008, Anticipated performance index of some tree species considered for green belt development in and around an urban area: A case study of Varaasi city, India, J. Environ. Manage., 88 (4), 1343-1349.

[13] Arnon, D.I., 1949, Copper enzymes in isolated chloroplasts: Polyphenoloxidise in Beta vulgaris, Plant Physiol., 24 (1), 1-15.

[14] Achakzai, K., Khalid, S., Adrees, M., Bibi, A., Ali, S., Nawaz, R., and Rizwan, M., 2017, Air pollution tolerance index of plants around brick kilns in Rawalpindi, Pakistan, J. Environ. Manage., 190, 252-258.

[15] Singh, S.K., and Rao, D.N., 1983, Evaluation of plants for their tolerance to air pollution, Proc. Symp. Air Pollut. Control, 83, 218-224. 
[16] Bakiyaraj, R., and Ayyappan, D., 2014, Air pollution tolerance index of some terrestrial plants around an industrial area, Int. J. Mod. Res. Rev., 2 (1), 1-7.

[17] Ganguly, S., Das, M., and Mukherjee, A., 2017, Anticipated performance index (API) of some selected phanerophytes considered for green belt development, RJPBCS, 8 (3), 525-532.

[18] Zhang, P.Q., Liu, Y.J., Chen, X., Yang, Z., Zhu, M.H., and Li, Y.P., 2016, Pollution resistance assessment of existing landscape plants on Beijing streets based on air pollution tolerance index method, Ecotoxicol. Environ. Saf., 132, 212-223.

[19] Liu, Y.J., and Ding, H., 2008, Variation in air pollution tolerance index of plant near a steel factory: Implications for landscape-plant species selection for industrial areas, WSEAS Trans. Environ. Dev., 4 (1), 24-30.

[20] Nadgórska-Socha, A., Kandziora-Ciupa, M., Trzesicki, M., and Barczyk, G., 2017, Air pollution tolerance index and heavy metal bioaccumulation in selected plant species from urban biotopes, Chemosphere, 183, 471-482.

[21] Balasubramanian, A., Prasath, C.N.H., Gobalakrishnan, K., and Radhakrishnan, S., 2018, Air pollution tolerance index (APTI) assessment in tree species of Coimbatore urban city, Tamil Nadu, India, IJECC, 8 (1), 27-38.

[22] Rai, P.K., Panda, L.L.S., Chutia, B.M., and Singh, M.M., 2013, Comparative assessment of air pollution tolerance index (APTI) in the industrial (Rourkela) and non-industrial area (Aizwal) of India: An eco-management approach, Afr. J. Environ. Sci. Technol., 7 (10), 944-948.

[23] Rathore, D.S., Kain, T., and Gothalkar, P., 2018, A study of air pollution status by estimation of APTI of certain plant species around Pratapnagar circle in Udaipur city, Int. J. Agric. Environ. Biotechnol., 11 (1), 33-38.

[24] Padmavathi, P., Cherukuri, J., and Reddy, M.A., 2013, Impact of air pollution on crops in the vicinity of a power plant: a case study, IJERT, 2 (12), 36413651.

[25] Singh, S.K., Rao, D.N., Agrawal, M., Pandey, J., and Naryan, D., 1991, Air pollution tolerance index of plants, J. Environ. Manage., 32 (1), 45-55.

[26] Thambavani, S.D., and Sabitha, M.A., 2011, Variation in air pollution tolerance index and anticipated performance near a sugar factory: implication for landscape-plant selection for industrial areas, $J R B, 7,494-502$. 